\title{
Distributive Justice: A Perspective from Islamic Economics Literature
}

\author{
Shafinah Rahim ${ }^{\mathrm{a}}$ \\ ${ }^{a}$ Faculty of Economics and Business, Universiti Malaysia Sarawak
}

\begin{abstract}
This conceptual research paper intends to provide a summative introductory to an important economic concept; distributive justice from a purely Islamic perspective. Despite its relevance to the prevailing socio-economic problems and role in our daily economic activities both at micro and macro levels, most discussions related to distributive justice are often rooted to works of western scholars. The efforts available are normally cursory in nature relative to processes of production and consumption. Justice being central to Islam in general and distribution an aspect that affects the wellbeing of people collectively awards the notion of distributive justice an interesting and significant place as an independent subject matter of analysis.
\end{abstract}

Keywords: Distribution, Justice, Islamic Economics

\section{Introduction}

In recent years, distributive justice has emerged as an important topic among Muslim scholars of Islamic Economics. Underlying these discussions is the strong Islamic ethics of providing basic subsistence, for the most disadvantaged members of society. This involves individual obligation and personal piety as well as a state responsibility for social welfare. The ethical principle is formalized as one of the five pillars of faith in the form of tax of surplus wealth known as zakat. 